\title{
Cell cycle specific induction of HL-60 cell differentiation and apoptosis by mycophenolic acid
}

\author{
Andreas Görtz ${ }^{1}$, Trevor J. Franklin ${ }^{2}$, Caroline Dive ${ }^{1}$ and John \\ A. Hickman ${ }^{1,3}$ \\ ${ }^{1}$ Cancer Research Campaign Molecular and Cellular Pharmacology Group, \\ School of Biological Sciences, University of Manchester, M13 9PT, UK \\ 2 Zeneca Pharmaceuticals, Alderley Park, Macclesfield, Cheshire, SK10 4TG, UK \\ ${ }^{3}$ corresponding author J.A. Hickman
}

Received 6.4.97; revised 1.7.97 accepted 14.7.97

Edited by M.L. Gougeon

\begin{abstract}
HL-60 cells undergo terminal differentiation and apoptosis in response to different types of sub-toxic and toxic perturbations respectively. The mechanism by which cells sense different amounts of perturbation to activate pathways that lead to the engagement of a relevant biological response is not known. The response of HL-60 cells to treatment with the immunosuppressant mycophenolic acid (MPA), a specific inhibitor of dGTP/GTP-synthesis, allowed quantitation of a metabolic perturbation which triggered a cellular response. 1.5 $\mu \mathrm{M}$ MPA induced $38 \%$ terminal differentiation to CD14 positive, early monocyte-like cells and $22 \%$ cell death by apoptosis, whereas $3 \mu \mathrm{M}$ MPA induced $70 \%$ apoptosis but no differentiation. Despite the difference in biological outcomes, $72 \mathrm{~h}$ exposure to both $1.5 \mu \mathrm{M}$ and $3 \mu \mathrm{M}$ MPA caused a similar ( $75 \%$ ) depletion of total GTP levels. Cells synchronized by centrifugal elutriation were treated with MPA. Elutriated cells were overall less sensitive to the effects of MPA but $3 \mu$ M MPA induced significantly less apoptosis and more differentiation in an elutriation-enriched G1-population than in a population normally distributed in the cell cycle, suggesting that the effects of MPA in S-phase may subsequently lead to cell death. However, analysis of apoptosis by using a terminal deoxynucleotidyltransferase assay and measurement of bromodeoxyuridine incorporation showed that apoptosis was engaged in G1. Analysis of the phosphorylation status of the retinoblastoma protein demonstrated that $\mathrm{Rb}$ was hypophosphorylated prior to apoptosis and that in apoptotic cells, separated by flow cytometry, $\mathrm{Rb}$ protein was absent, presumably due to proteolysis. The loss of $\mathrm{Rb}$ protein did not appear to permit transit to S-phase, and was not accompanied by an expression of c-Myc. Surprisingly, therefore, an antimetabolite inducing a loss of GTP brought about cell death by apoptosis in the G1 phase of the cell cycle.
\end{abstract}

Keywords: mycophenolic acid; apoptosis; differentiation; cell cycle

Abbreviations: $A b$, antibody; $A O$, acridine orange; $B S A$, bovine serum albumin; BrdU, bromodeoxyuridine; DMSO, dimethylsulfoxide; FACS, fluorescence activated cell sorting; FIGE, field inversion gel electrophoresis; HU, hydroxyurea; ICE, interleukin-1 $\beta$-converting enzyme; IMP, inosine-5'-monophosphate; IMPDH, inosinate monophosphate dehydrogenase; kb, kilobase(s); MPA, mycophenolic acid; MTX, methotrexate; NMF, N-methylformamide; NBT, nitroblue tetrazolium; PALA, N-phosphonacetyl-L-asparate; PBS, phosphate-buffered saline; $\mathrm{PI}$, propidium iodide; SDS, sodium dodecylsulfate; TB, trypan blue; TPA, 12-0-tetradecanoylphorbol 13-acetate; TdT, terminal deoxynucleotidyltransferase; TOC, toluene-4-sulfanyl chloride

\section{Introduction}

The promyelocytic HL-60 human leukemic cell line provides a valuable model to study the cellular response to drug treatment (Birnie, 1988). HL-60 cells can be induced to differentiate into granulocytes or monocytes by various agents with different potencies and mechanisms of action (Ahmed and Weideman, 1995; Bunce et al, 1995; Gallagher et al, 1979; Langdon and Hickman, 1987; Lucas et al, 1983; Martin et al, 1990). Interestingly, antimetabolites such as mycophenolic acid (MPA), hydroxyurea (HU) and methotrexate (MTX) (Pratt et al, 1994) were consistently shown to induce low levels of HL-60 differentiation when applied at concentrations which were marginally lower than those which mediated toxicity. We have suggested that although some of these drugs have been termed 'differentiating agents' the engagement of differentiation is an inherent, phenotypicallydetermined response of these cells to modest amounts of metabolic perturbation (Beere and Hickman, 1993). This idea places the phenotype of the cell as the major determinant of the outcome of drug treatment (cell death, differentiation or resistance) rather than the type of damage imposed by the drug. How cells distinguish between different levels of perturbation as to engage different biological end-points (differentiation or apoptosis) is not clear. Presumably a quantitative and/or qualitative difference in perturbation is detected.

In order to investigate the relationship between quantitative changes in metabolism incurred by drug treatment and biological outcome we sought to use an agent with a well-defined locus of action. MPA is a fermentation product of several Penicillium species and a potent and specific inhibitor of inosinate monophosphate dehydrogenase (IMPDH) (EC. 1.2.1.14) (Franklin and Cook, 1969; Sintchak et al, 1996). IMPDH catalyses the oxidation of inosine-5'-monophosphate (IMP) to xanthosine$5^{\prime}$ monophosphate (XMP) and subsequently generates the de novo synthesis of dGTP/GTP nucleotides (Allison et al, 1993). Although MPA and its analogs are widely used as immunosuppressive agents, the exact mechanism(s) by which IMPDH inhibition and dGTP/GTP depletion induces toxicity are unknown. A recent report suggested that MPA 
toxicity is mediated by inhibition of RNA primed DNA synthesis due to GTP depletion (Catapano et al, 1995). MPA induced differentiation was suggested to be a result of GTP depletion (Sokoloski et al, 1986; Sokoloski and Sartorelli, 1985).

We have found that HL-60 cells engage differentiation and/or apoptosis according to MPA concentration. However, MPA concentrations which induced these different endpoints produced the same overall reduction in GTP levels suggesting that either there were qualitative differences in the 'sensing' of the fall in GTP, for example dependent upon the position in the cell cycle, or that heterogenous changes were invoked by MPA.

\section{Results}

\section{Cellular responses to MPA}

In order to determine the cellular response of HL-60 cells to treatment with MPA, HL-60 cells were continuously incubated with different concentrations of drug for $96 \mathrm{~h}$. The different responses of differentiation and/or apoptosis were assessed only in those cells which retained membrane integrity of $>80 \%$, as measured by the exclusion of the vital dye trypan blue. Figure $1 \mathrm{~A}$ shows a concentration-response curve, from which we chose $1.5 \mu \mathrm{M}$ MPA as the optimal concentration for the differentiation of HL-60 cells (38\%) (22\% apoptosis) and $3 \mu \mathrm{M}$ MPA as the optimum concentration for the induction of apoptosis $(70 \%)$ with no differentiation. A kinetic analysis of the onset of both differentiation and apoptosis showed that $1.5 \mu \mathrm{M}$ MPA induced maximal differentiation by $96 \mathrm{~h}$ (Figure 1B). The engagement of apoptosis occurred more rapidly than that of differentiation, so that at $48 \mathrm{~h} 25 \%$ apoptosis had occurred (Figure 1C). No morphological or functional characteristics (NBT positivity) of these cells were suggestive of the process of differentiation prior to the engagement of apoptosis. Differentiated cells expressed the CD14 antigen (data not shown) and we were unable to detect any CD14 positive cells after treatment with $3 \mu \mathrm{M}$ MPA.

Treatment of HL-60 cells with $1.5 \mu \mathrm{M}$ and $3 \mu \mathrm{M}$ MPA for $24 \mathrm{~h}$, followed by a wash and addition of guanosine $(50 \mathrm{mM})$ prevented apoptosis and/or differentiation (Figure $1 \mathrm{~B}$ and $\mathrm{C}$ ). Both concentrations of MPA had induced a G1 block by $12 \mathrm{~h}$ and a fall in GTP by $3 \mathrm{~h}$. This suggests that the cells have to be exposed to the drug and/or a fall in GTP must take place for $>24 \mathrm{~h}$ in order to commit to the apoptotic or differentiation pathways. Indeed, significant amounts of differentiation ( $>20 \%$ ) were not observed until after $48 \mathrm{~h}$ of continuous exposure to $1.5 \mu \mathrm{M}$ MPA, followed by guanosine (data not shown). Similar results were observed with respect to apoptosis, where $3 \mu \mathrm{M}$ MPA induced $>20 \%$ cell death only after $48 \mathrm{~h}$ of drug exposure (data not shown).

The detection of a non-random pattern of DNA cleavage (Figure 2A) was coincident with the appearance of morphological features of apoptosis, assessed as chromatin condensation by fluorescence microscopy (Figure 2B and $\mathrm{C}$ ). Interestingly, although we found that etoposide, camptothecin and $\mathrm{N}$-methylformamide induced fragments of 180-200 bp integers (the DNA 'ladder') in HL-60 cells (Beere et al, 1993, 1995) MPA did not (data not shown), but instead consistently produced unresolved fragments of low molecular weight when analyzed by conventional gel electrophoresis. Analysis of DNA cleavage by FIGE after MPA treatment showed that, as with the other agents, $50 \mathrm{~kb}$ fragments of DNA were formed (Figure 2A). We and others have shown that DNA fragments of $30-50 \mathrm{~kb}$ are a more conserved feature of apoptotic cells than the internucleosomal cleavage pattern (Beere et al, 1995; Brown et al, 1993; Oberhammer et al, 1993).
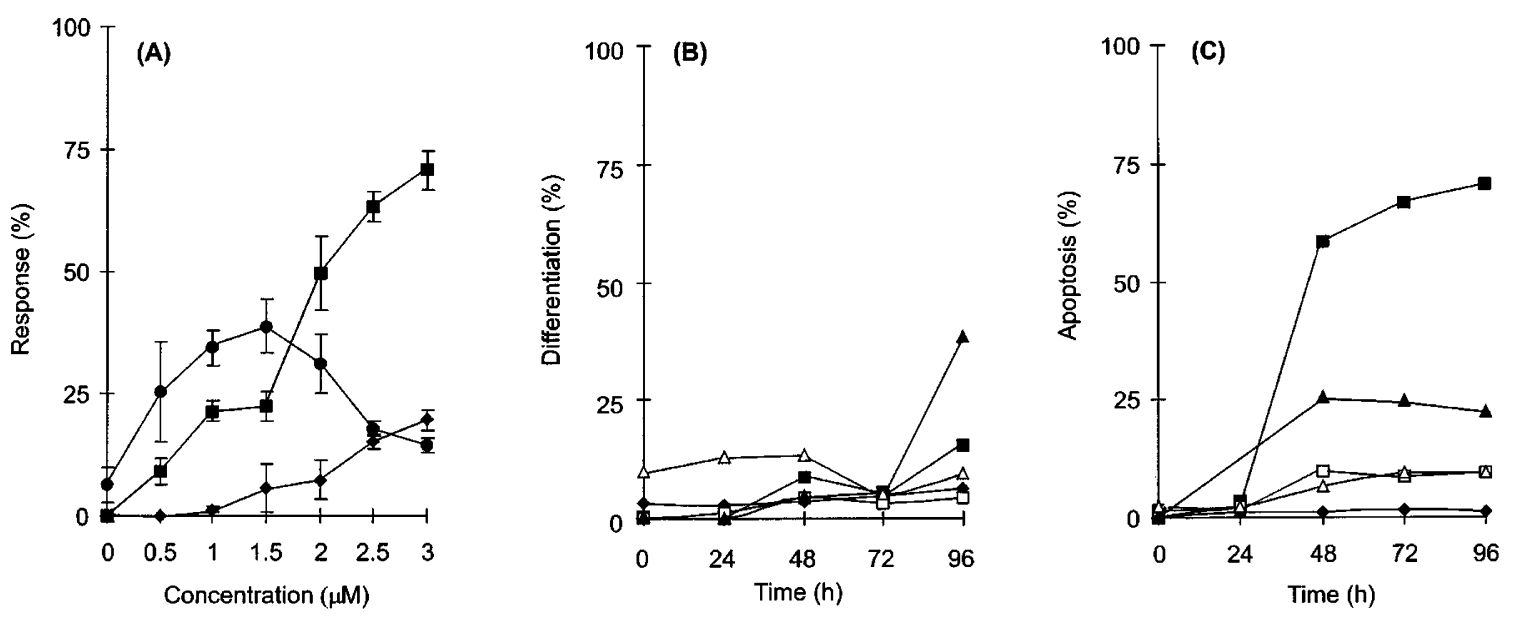

Figure 1 Determination of the response of HL-60 cells to MPA treatment in percent (\%). (A) Concentration-response curve determined after $96 \mathrm{~h}$ of continuous incubation with MPA. NBT positive cells (0) were scored as terminally differentiated; cells with condensed chromatin ( $)$ were scored as apoptotic (see Materials and Methods); TB positive cells were scored as necrotic $(\bullet)(n=3, \pm$ S.D.). (B) Commitment to and kinetics of the induction of terminal differentiation after continuous incubation with $1.5 \mu \mathrm{M}$ MPA $(\boldsymbol{\Delta}) ; 24 \mathrm{~h}$ exposure to $1.5 \mu \mathrm{M}$ MPA followed by addition of $50 \mathrm{mM}$ guanosine $(\triangle)$; continuous incubation with $3 \mu \mathrm{M}$ MPA ( $\mathbf{\square})$, $24 \mathrm{~h}$ exposure to $3 \mu \mathrm{M}$ MPA followed by addition of $50 \mathrm{mM}$ guanosine ( $\square$ ). (C) Commitment to and kinetics of the induction of apoptosis after continuous incubation with $1.5 \mu \mathrm{M}$ MPA $(\boldsymbol{\Delta}) ; 24 \mathrm{~h}$ exposure to $1.5 \mu \mathrm{M}$ MPA followed by addition of $50 \mathrm{mM}$ guanosine $(\triangle)$; continuous incubation with $3 \mu \mathrm{M}$ MPA ( $\mathbf{\square})$; $24 \mathrm{~h}$ exposure to $3 \mu \mathrm{M}$ MPA followed by addition of $50 \mathrm{mM}$ guanosine $(\square)$. All results are the average of three independent determinations 

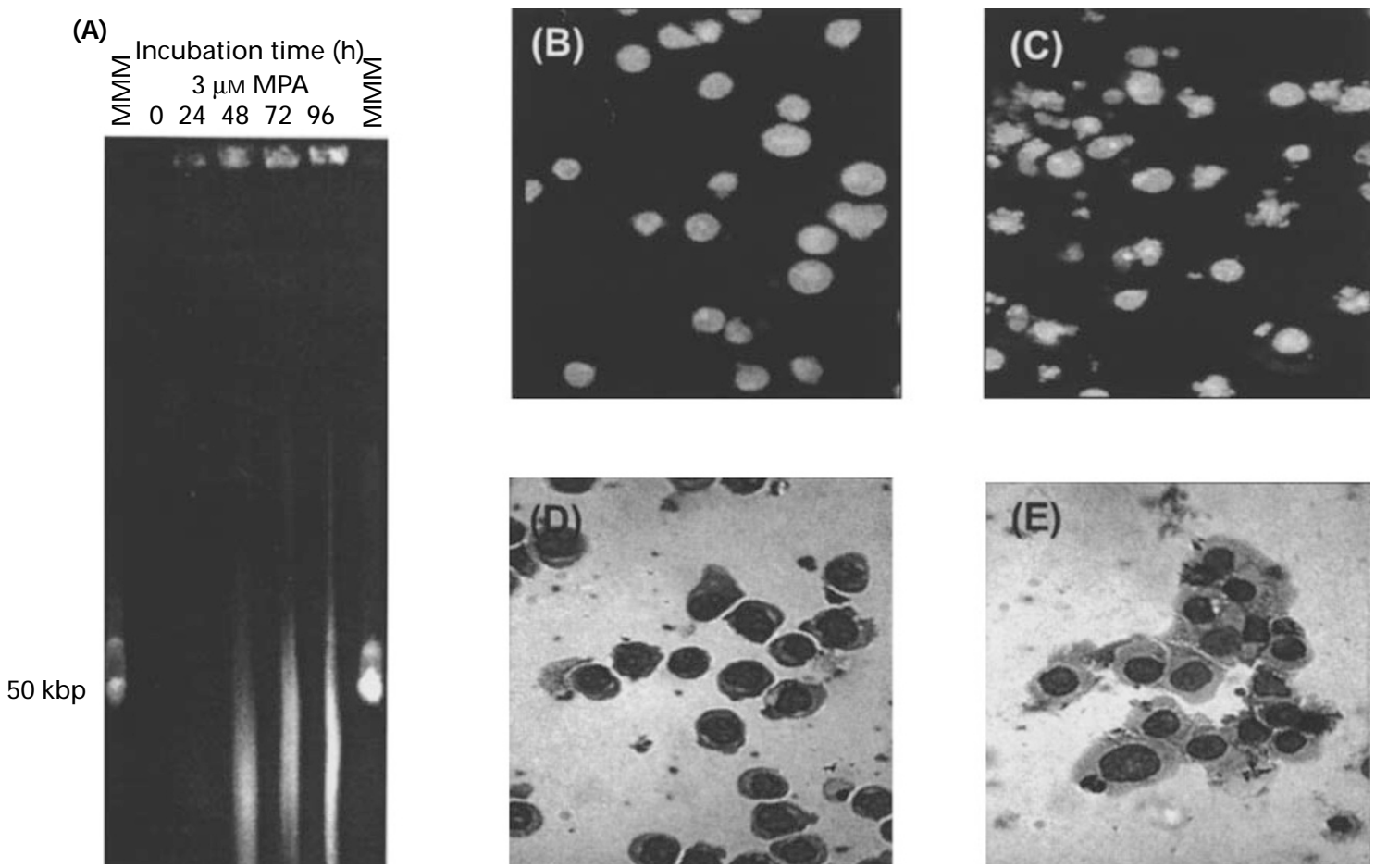

Figure 2 (A) Field inversion gel electrophoresis of DNA from HL-60 cells treated for between 24 and $96 \mathrm{~h}$ with $3 \mu \mathrm{M} \mathrm{MPA}$. (B) Fluorescent microscopy image of HL60 control cells and (C) HL-60 cells treated for $72 \mathrm{~h}$ with $3 \mu \mathrm{M}$ MPA and stained with acridine orange. (D) Light microscopy image of HL-60 control cells and (E) HL60 cells treated for $96 \mathrm{~h}$ with $1.5 \mu \mathrm{M}$ MPA and stained with Giemsa

The finding that $1.5 \mu \mathrm{M}$ MPA induced a differentiated phenotype similar to that of monocytes (Figure 2D and E) and a moderate percentage of apoptotic cells suggested that the low level of differentiation $(<50 \%)$, which was previously observed by other investigators (Allison et al, 1993; Sokoloski et al, 1986; Sokoloski and Sartorelli, 1985), was perhaps the result of concomitant cell death by apoptosis. A number of antimetabolites have been observed to be 'weak' inducers of differentiation ( $<50 \%)$ (Bodner et al, 1981) whereas agents like retinoic acid consistently induce $>70 \%$ differentiation (Martin et al, 1990). We considered that a single drug concentration of a 'weak' inducer may cause sub-populations of cells to undergo different biological responses (differentiation and apoptosis). To investigate this idea further HL-60 cells were analyzed for concomitant induction of differentiation and apoptosis in response to treatment with MTX. We found that a concentration of $12 \mathrm{nM}$ induced $36 \%$ differentiation and $35 \%$ apoptosis, supporting this idea.

\section{MPA induced depletion of GTP and ATP nucleotides}

Total dGTP plus GTP were measured by high performance liquid chromatography. The method is technically limited and did not permit separate estimation of dGTP and GTP. When the rate of GTP (GTP and dGTP) depletion in response to MPA was analyzed, it was found that GTP was stably reduced after $3 \mathrm{~h}$ (Figure 3), although differentiation and apoptosis were not engaged until after $24 \mathrm{~h}$ (Figure 1). $1.5 \mu \mathrm{M}$ MPA

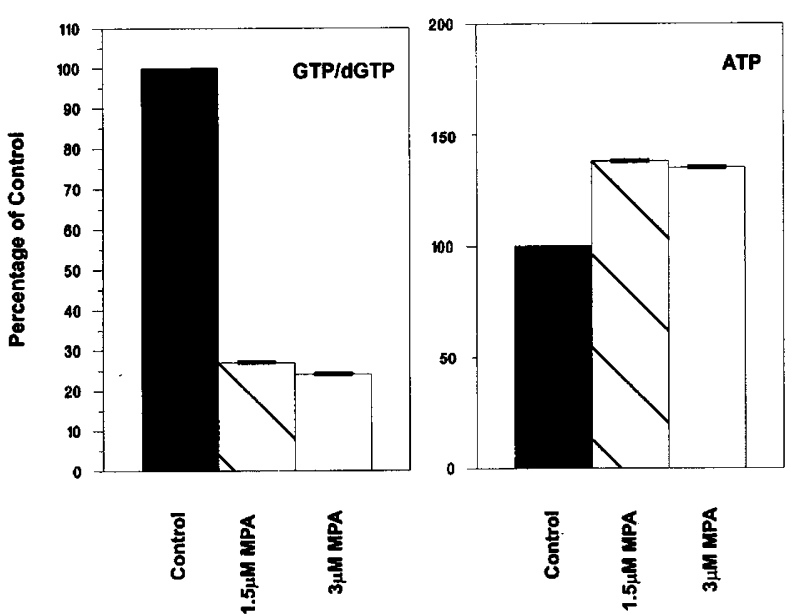

Figure 3 Changes in the cellular concentrations of GTP and ATP after treatment with MPA. HL-60 cells were continuously incubated with $1.5 \mu \mathrm{M}$ MPA (hatched boxes) and $3 \mu \mathrm{M}$ MPA (white boxes) and samples $\left(10^{8}\right.$ cells) were analyzed by HPLC for [dGTP/GTP] after $3 \mathrm{~h}$ and [dATP/ATP] after $24 \mathrm{~h}$ (plotted as a $\%$ of the control values of 4.8 and $35 \mu \mathrm{g} / \mathrm{ml} / 10^{8}$ cells respectively)

reduced the constitutive GTP levels by $73 \%$ after $3 \mathrm{~h}$ and $3 \mu \mathrm{M}$ MPA reduced GTP levels by $76 \%$ (Figure 3 ). ATP concentrations were increased by $35 \%$ after $24 \mathrm{~h}$ exposure to $1.5 \mu \mathrm{M}$ and by $38 \%$ after $24 \mathrm{~h}$ exposure to $3 \mu \mathrm{M}$ MPA (Figure 3). Commitment to differentiation and apoptosis was associated with reduced ATP levels which fell rapidly to 
$41 \%$ of control levels after $1.5 \mu \mathrm{M}$ MPA and to $42 \%$ at $96 \mathrm{~h}$ after $3 \mu \mathrm{M}$ MPA (data not shown).

\section{Induction of differentiation or apoptosis by MPA is cell cycle dependent}

MPA is a specific inhibitor of IMPDH which effectively and rapidly decreases concentrations of GTP and dGTP (Allison et al, 1993; Eugui et al, 1990; Lowe et al, 1977; Sokoloski et al, 1986; Sokoloski and Sartorelli, 1985) (Figure 3). We argued that because of the heterogenous response to MPA, the different roles of GTP and dGTP during each phase of the cell cycle may influence, in a qualitative way, the cellular response to a fall in (GTP). Clearly, the need for GTP and dGTP during S-phase is different from other phases of the cell cycle. Accordingly, we used centrifugal elutriation to enrich HL-60 cells in the G1/G0 phase of the cycle, where a fall in dGTP would be predicted to be less toxic because of the lack of effect on DNA synthesis. Cell populations enriched (>90\%) in G1/G0 or a fully reconstituted cell cycle population were treated with $3 \mu \mathrm{M}$ MPA, a concentration which completely inhibited any increase in cell number. Treatment of the elutriated populations with $1.5 \mu \mathrm{M}$ resulted in $<20 \%$ differentiation and no significant apoptosis compared to controls. After $3 \mu \mathrm{M} \mathrm{MPA}$, the reconstituted, elutriated population, representing all phases of the cell cycle, underwent $19 \%$ differentiation and $49 \%$ apoptosis (Figure $4 \mathrm{~A}$ ) whereas an enriched G1/G0 population underwent $27 \%$ differentiation and $20 \%$ apoptosis by $96 \mathrm{~h}$ (Figure 4A). The cell cycle profiles for the elutriated cells are shown in Figure $4 \mathrm{~B}$. The process of cell elutriation clearly reduced the overall response to MPA, presumably due to the low temperature experienced during the procedure (see Materials and Methods). Nevertheless, the ratio of cells undergoing differentiation or apoptosis in a cell cycle mixed population of elutriated cells is essentially unchanged from unelutriated cells.

\section{MPA treated HL-60 cells accumulate in the G1/G0-phase of the cell cycle prior to the engagement of differentiation or apoptosis}

Continuous treatment of HL-60 cells with $1.5 \mu \mathrm{M}$ MPA induced a mixture of both differentiating cells and those which underwent apoptosis (Figure 1). Analysis of their progression through the cell cycle by measurement of the incorporation of bromodeoxyuridine and staining with propidium iodide showed that by $12 \mathrm{~h}$ significant numbers of cells had accumulated in G1 phase of the cell cycle (Figure $5 \mathrm{~A}$ ) accompanied by a fall in S-phase. The accumulation of cells in $\mathrm{G} 1$ was maintained for $72 \mathrm{~h}$, compatible with their commitment to functional, terminal differentiation. Exposure to $3 \mu \mathrm{M}$ MPA resulted in a $90 \%$ decrease in BrdU incorporation (Figure 5B). An accumulation of HL-60 cells in G1 phase was observed by $12 \mathrm{~h}$ in response to both $1.5 \mu \mathrm{M}$ and $3 \mu \mathrm{M}$ MPA (Figure 5A and B). With increasing exposure time $(>12) \mathrm{h}$ to $3 \mu \mathrm{M}$ MPA the number of cells in $\mathrm{G} 1$ then decreased from $68 \%$ at $12 \mathrm{~h}$ to $43 \%$ at $72 \mathrm{~h}$, concomitantly with an increase in apoptosis. We investigated the hypothesis that cells may die from $\mathrm{G} 1$ phase by a flow cytometric analysis of DNA strand
A
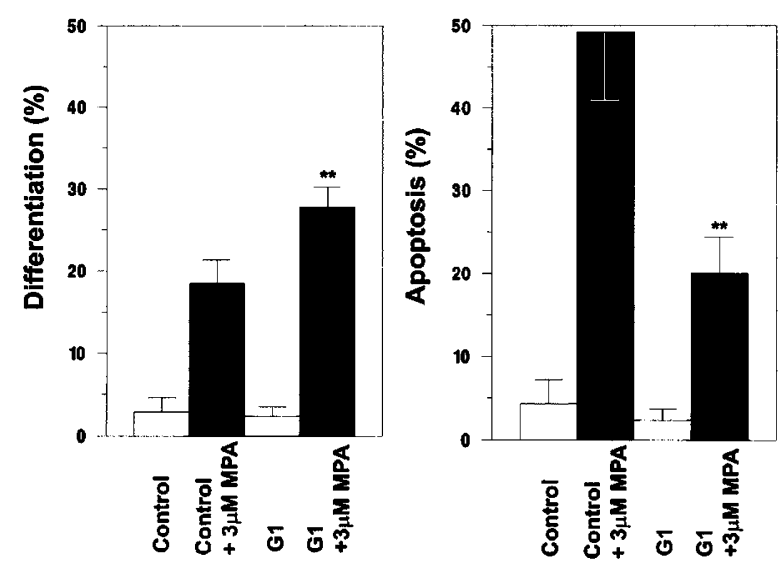

B

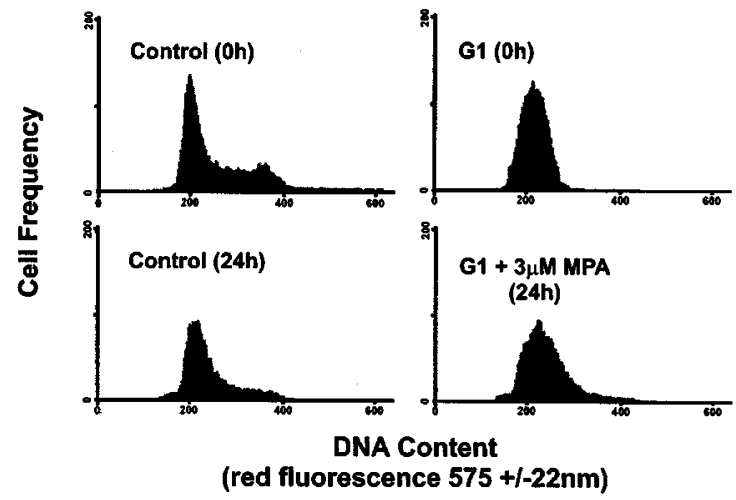

Figure 4 Cell cycle-dependent induction of differentiation or apoptosis induced in populations of cells separated by centrifugal elutriation. (A) Induction of differentiation and apoptosis in response to $96 \mathrm{~h}$ continuous incubation with $3 \mu \mathrm{M}$ MPA. Apoptosis of a reconstituted population of elutriated cells consisting of all phases of the cell cycle (see B below) was compared with apoptosis of a G0/G1 enriched HL-60 cell populations as shown ( $n=3,+$ S.D., ${ }^{*} P=0.05$ for the two drug treated samples). (B) Cell cycle distributions of a reconstituted control population after 0 and $24 \mathrm{~h}$ in culture $\left(37^{\circ} \mathrm{C}\right)$ and a G0/G1 enriched $\mathrm{HL}-60$ cell population after $0 \mathrm{~h}$ and $24 \mathrm{~h}$ exposure to $3 \mu \mathrm{M}$ MPA

breaks using the TdT assay to detect apoptotic cells (Figure 6). The results indicated that $>90 \%$ of $\mathrm{HL}-60$ cells treated with $3 \mu \mathrm{M}$ MPA appeared to be induced to undergo apoptosis from $\mathrm{G} 1$, whereas only $5 \%$ of apoptotic HL-60 cells had an Sphase DNA content. Significant numbers of apoptotic cells in a sub-G1 population were presumed to consist of apoptotic fragments.

\section{Changes in Rb phosphorylation according to MPA concentration and the outcome of treatment}

The accumulated data above suggested that when $1.5 \mu \mathrm{M}$ MPA induced differentiation, HL-60 cells did so from that population that was exposed to MPA in G1. Those cells that 

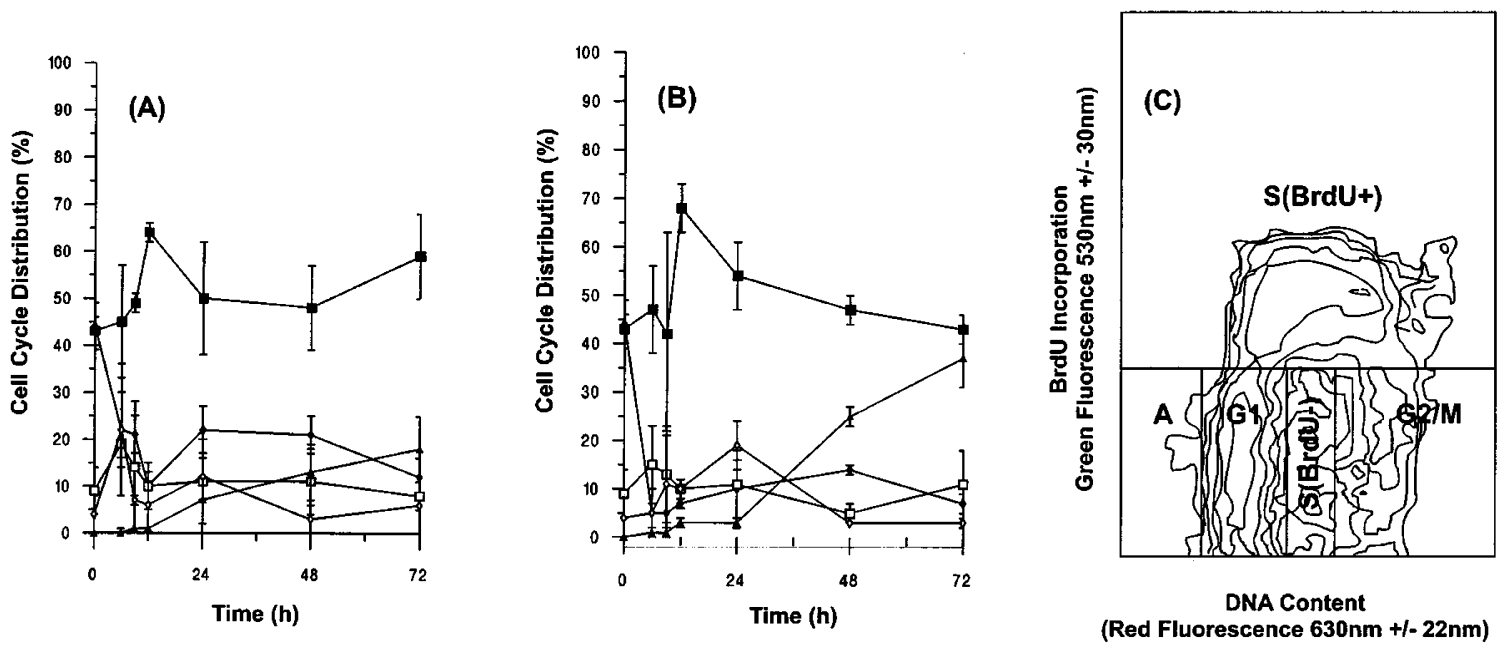

Figure 5 Analysis of cell cycle distribution measured by combined staining of cells with propidium iodide and incorporation of bromodeoxyuridine into DNA. Gating was performed as shown in (C). Cell cycle fractions are shown in percentage of total HL-60 cell populations ( $\mathbf{\square}: \mathrm{G} 1 ; \diamond: \mathrm{S}(\mathrm{BrdU}-)$; $\bullet$ : $(\mathrm{BrdU}+)$; $\square: \mathrm{G} 2)$. (A) Continuous treatment with $1.5 \mu \mathrm{M}$ MPA. (B) Continuous treatment with $3 \mu \mathrm{M}$ MPA. The percentage of cells which had engaged apoptosis, measured by the percentage of cells which had appeared in the sub-G1 population of propidium iodide-stained cells is also shown ( $\boldsymbol{\Delta})$, denoted as box ' $A$ ' in $(\mathbf{C})$

had traversed the cell cycle during exposure to MPA, returned to $\mathrm{G} 1$ where they subsequently became apoptotic. Whereas after $3 \mu \mathrm{M}$ MPA, which induced apoptosis, accumulation in G1 was followed by apoptosis, irrespective of where in the cell cycle the cells had been exposed to MPA (Figure 6). It was considered possible that apoptosis may occur as dGTP/GTPdepleted cells attempted DNA synthesis. However, Western blotting of the retinoblastoma protein, $\mathrm{Rb}$, at various times, did not support this idea (Figure 7A). Exponentially growing $\mathrm{HL}$ 60 cells showed a single band of hyperphosphorylated protein, indicative of a population with a high growth fraction. Cells treated with the strong differentiating agent NMF (170 mM) had predominantly hypophosphorylated Rb, as expected from cells which have accumulated in G1 (data not shown) (Beere et al, 1993). In contrast, HL-60 cells treated with $3 \mu \mathrm{M}$ MPA showed a mixture of hyper- and hypophosphorylated Rb at $48 \mathrm{~h}$. At $72 \mathrm{~h}$ and $96 \mathrm{~h}$, where $>50 \%$ of cells were apoptotic, cells showed a progressive decrease in hypophosphorylated form of the protein, suggesting proteolysis of $\mathrm{Rb}$. The fall in the amount of $\mathrm{Rb}$ protein presents conditions possibly permissive for the release of transcription factors promoting entry into $S$ phase. However, Western blotting of the c-Myc protein did not support this idea (Figure $7 A)$. Because cell populations were heterogenous with respect to death and differentiation, we confirmed that the reduction of $\mathrm{Rb}$ was associated with the apoptotic cells using fluorescence-activated cell sorting (Figure 7B). Figure 7C shows that the apoptotic population, separated on the basis of Hoechst dye fluorescence, had no Rb protein as detected by Western blotting. Taken together, the data supports the flow cytometric results (Figures 5 and 6) suggesting that both death and differentiation occur from the G1 phase.

\section{Discussion}

We have suggested previously that both drug-induced terminal differentiation and apoptosis may constitute an adaptive and conserved response of some cells to cellular perturbation (Beere and Hickman, 1993; Dive and Hickman, 1991). The biological endpoints of terminal differentiation and apoptosis may be engaged differentially depending upon either the quantity or quality of perturbation sustained. The results of our experiments with MPA, reported here, support the latter conclusion but, as discussed below, this is a drug-specific phenomenon. Thus, a fall in dGTP/GTP induced by $1.5 \mu \mathrm{M}$ MPA induced the coincident appearance of both differentiated and apoptotic cells (Figure 1). Both the kinetics of apoptosis, which were more rapid than that of differentiation (Figure 1), and the measurement of CD14, a marker of terminal differentiation, did not support the idea that apoptotic cells were those which had first differentiated. Rather, and not surprisingly, it appeared that the consequences of a fall in GTP/dGTP were different according to whether the cells had passed the G1/S boundary or not, providing qualitatively different cellular damage. Thus, an enriched population in G0/G1 was prevented from entering S-phase and preferentially underwent differentiation, whereas those cells which had entered S-phase, and were then subjected to limited dGTP pools whilst attempting DNA synthesis, completed the cell cycle and then initiated apoptosis in G1 (Figures 3 and 4). It has been suggested previously that antimetabolites such as MPA may induce DNA damage in S-phase (Linke et al, 1996) and we presume that in HL-60 cells some non-p53 mechanism of DNA damage 'sensing' is responsible for engaging a subsequent cell death. This is congruent with the results from our experiments with methotrexate (data not shown), a dihydrofolate reductase and thymidylate synthase inhibitor (Pratt et al, 1994), which also simultaneously induced a mixture of differentiated and apoptotic cells (data not shown). In the case of methotrexate, the reduction of thymidine pools induces DNA strand breaks in nascent DNA, possible because of 
A

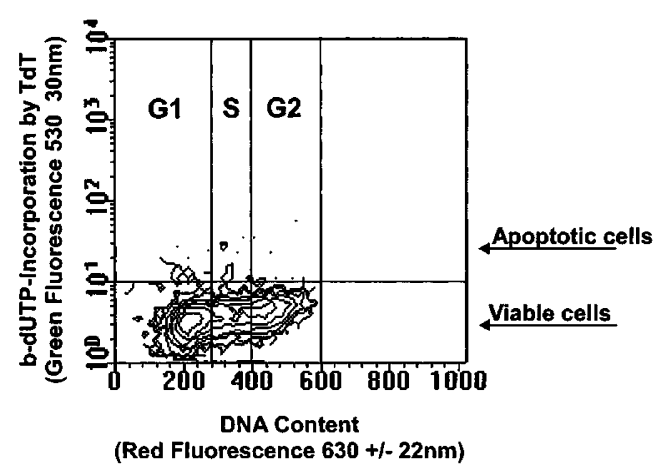

B

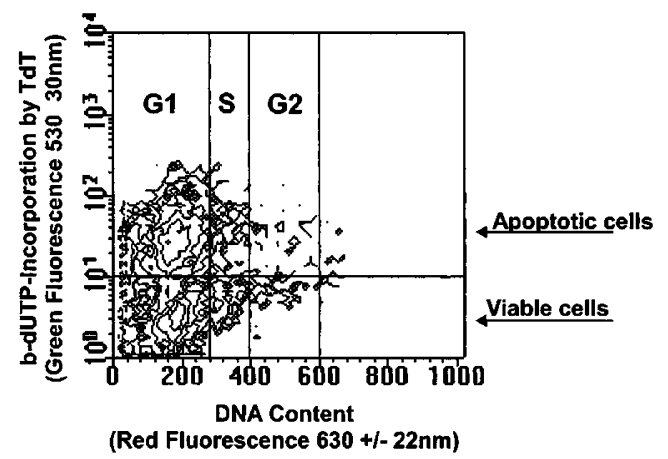

Figure 6 Analysis of apoptosis measured by combined staining of cells with propidium iodide and TdT mediated labelling of apoptotic DNA strand breaks with biotinylated deoxyuridine triphosphate. (A) Untreated HL-60 cell control population. (B) $72 \mathrm{~h}$ treatment with $3 \mu \mathrm{M}$ MPA

the mis-incorporation of deoxyuridine. In cells which have not initiated DNA synthesis, such as the G0/G1-enriched population used here, the metabolic perturbations induced by MPA and methotrexate engage a different response, differentiation. Interestingly, a survey of those compounds, which induce terminal differentiation of HL-60 cells suggests that many of them are non-genotoxic. For example, we recently showed that one of the polar solvents (NMF) which induces $>80 \% \mathrm{HL}-60$ cell differentiation with little toxicity (Beere et al, 1993) does not cause strand breaks (Beere et al, 1995). On the other hand, frankly genotoxic compounds such as the topoisomerase poisons and alkylating agents have not been demonstrated to induce efficient differentiation. Thus, in the case of MPA and methotrexate, the outcome of perturbation is not wholly dependent upon its quantity (e.g. a fall in GTP) followed by a conserved cellular response to this perturbation, but also on its quality. It is not clear whether with non-genotoxic and potent differentiating agents, like DMSO or NMF, the cellular response is solely related to the quantity of damage (such as protein or membrane perturbation) or to some qualitative aspect of the perturbation induced. These non-polar solvents have an ill-defined mechanism of action, making it dificult to directly quantitate 'damage' according to concentration. We are investigating this currently.
Interestingly, $1.5 \mu \mathrm{M}$ MPA and $3 \mu \mathrm{M}$ MPA brought about an identical and rapid decrease in dGTP/GTP, but induced different amounts of apoptosis (Figures 1 and 3). One possibility is that increasing concentrations of MPA may have different effects on the depletion of discrete pools of GTP and/or dGTP. HGPRT deficient S49 cells, which lack the ability to convert Guo into GTP and dGTP, could not be rescued with dGTP, indicating that MPA toxicity is mainly the result of GTP depletion (Cohen et al, 1981). Analysis of the cell cycle provided some clues as to how the cells were responding differently to different concentrations of MPA. Treatment with both $1.5 \mu \mathrm{M}$ and $3 \mu \mathrm{M}$ MPA induced an accumulation of cells in G1 after $12 \mathrm{~h}$ (Figure 5). Cells treated with $1.5 \mu \mathrm{M}$ MPA accumulate in G1 and subsequently gained biochemical features of terminal differentiation after $72 \mathrm{~h}$ (Figure 1). Those treated with $3 \mu \mathrm{M}$ MPA also accumulated in G1 (Figure 6) to die by apoptosis there. This was supported by a cell cycle analysis using BrdU, a flow cytometric analysis of the production of DNA strand breaks (Figure 5) and by analysis of the phosphorylation status of the retinoblastoma protein (Figure 7A). The data showed that cells treated with $3 \mu \mathrm{M}$ MPA accumulated in $\mathrm{G} 1$ by $48 \mathrm{~h}$ (Figure 5) compatible with the appearance of a more mobile form of the $\mathrm{Rb}$ protein, presumed to be hypophosphorylated (Figure 7A). When cells committed to differentiation after $1.5 \mu \mathrm{M}$ MPA the amount of the hypophosphorylated form of $\mathrm{Rb}$ continued to increase, as expected (data not shown) and there was a maintenance of the amount of $\mathrm{Rb}$ protein, whereas $72 \mathrm{~h}$ after $3 \mu \mathrm{M}$ MPA, Rb was degraded in apoptotic cells as demonstrated by cell sorting (Figure 7B and $\mathrm{C}$ ). Proteolytic breakdown of $\mathrm{Rb}$ into $\mathrm{p} 68$ and $\mathrm{p} 48$ fragments in response to an apoptosis inducing concentration of ara-C has previously been demonstrated by An and Dou (1996) who found that only the hypophosphorylated form of $\mathrm{Rb}$ is a putative substrate for an ICE like protease.

In summary, although $1.5 \mu \mathrm{M}$ MPA and $3 \mu \mathrm{M}$ MPA both induced the same fall in dGTP/GTP, and their effects were completely reversible by guanosine, suggesting an IMP dehydrogenase locus of action, the cellular response to these two concentrations of MPA was different. $3 \mu \mathrm{M}$ MPA only induced apoptosis after all the cells had accumulated in $\mathrm{G} 1$, an unusual effect for an antimetabolite considered to be cytotoxic because of the inhibition of DNA synthesis. Recent results from Linke et al (1996) have suggested that antimetabolites such as PALA induce biochemical changes that are 'sensed' in G1 phase, causing a G1 checkpoint. $1.5 \mu \mathrm{M}$ MPA on the other hand induced significant amounts of differentiation. What is being 'sensed' differently here remains to be established. Two recent studies investigated the possible inhibitory effects of MPA on signal transduction (Moorman et al, 1996; Yan et al, 1995). In addition, increasing concentrations of MPA were demonstrated to have differential effects on the mRNA levels of IMPDH type I and type II (Kiguchi et al, 1990). One possibility is that although the total amount of dGTP/GTP was the same after both concentrations of MPA, discrete intracellular pools may exist which are depleted heterogeneously, 
A

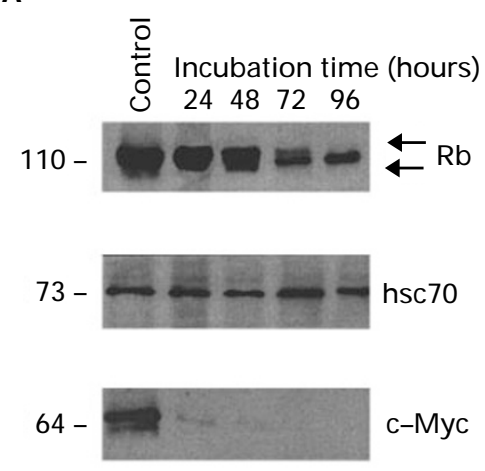

B

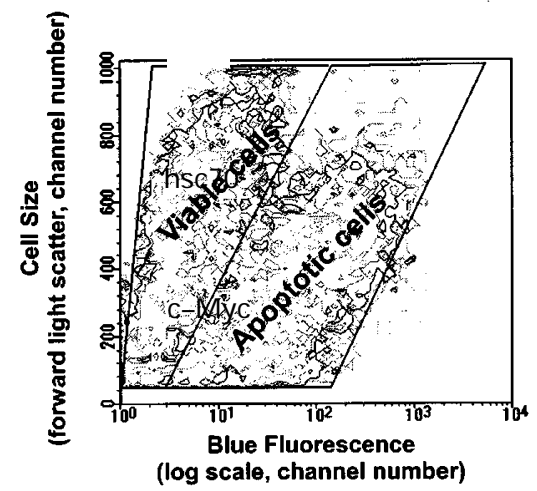

C

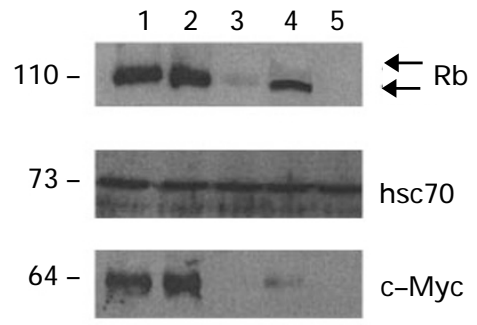

Figure 7 Analysis of proteins by Western blotting. HL-60 cells were continuously incubated for $96 \mathrm{~h}$ with $3 \mu \mathrm{M}$ MPA and at $24 \mathrm{~h}$ intervals were analyzed for $\mathrm{Rb}$ and $\mathrm{c}-\mathrm{Myc}$ proteins. Membranes were probed with an antibody to hsc70 to ensure equal loading. Arrows indicate hypophosphorylated and hyperphosphorylated forms of $\mathrm{Rb}$. (B) Cells were treated for $96 \mathrm{~h}$ with $3 \mu \mathrm{M}$ MPA, stained with Hoechst dye and sorted for viable and apoptotic cell fractions by FACS (see Methods). Reconstituted and sorted fractions were analyzed for $\mathrm{Rb}$ and $\mathrm{c}-\mathrm{Myc}$ protein contend as shown in (C). 1, unsorted untreated HL-60 cell population; 2, sorted, untreated and reconstituted HL-60 cell population; 3 , unsorted HL-60 cell population treated for $96 \mathrm{~h}$ with $3 \mu \mathrm{M}$ MPA; 4 , viable $\mathrm{HL}-60$ cell fraction after $96 \mathrm{~h}$ treatment with $3 \mu \mathrm{M}$ MPA; 5 , apoptotic HL-60 cell fraction after $96 \mathrm{~h}$ treatment with $3 \mu \mathrm{M}$ MPA

permitting the engagement of different responses. Whatever the precise mechanism, this study has shown that HL-60 cells can respond to a single quantitative fall in GTP/dGTP by undergoing both differentiation and/or apoptosis, and that in both cases, this occurs in the $\mathrm{G} 1$ phase of the cell cycle.
Materials and Methods

\section{Materials}

All materials were obtained from Sigma Chemical Co. (Poole, Dorset, United Kingdom) unless otherwise stated.

\section{Culture and treatment of cells}

HL-60 human myelomonocytic leukemia cells were maintained as described previously (Beere et al, 1993). For experiments using G1/G0 enriched samples, HL-60 cells were elutriated at $4^{\circ} \mathrm{C}$ in RPMI 1640 containing 5\% FCS and $2 \mathrm{mM}$ L-glutamine and reseeded in RPMl-1640 containing 10\% FCS, 2 mM L-glutamine, $100 \mathrm{mg} / \mathrm{ml}$ streptomycin and 100 units $/ \mathrm{ml}$ penicillin. Cells were routinely maintained in logarithmic phase growth between $2 \times 10^{5}$ and $1 \times 10^{6} \mathrm{celll} / \mathrm{ml}$ by biweekly subculture and had an approximate doubling time of $24 \mathrm{~h}$. MPA (Zeneca Pharmaceuticals, Macclesfield, UK) was prepared as a $1 \mathrm{mM}$ stock solution in distilled water and stored at $4^{\circ} \mathrm{C}$.

\section{Assessment of differentiation}

Differentiation of HL-60 cells was assessed by the nitroblue tetrazolium (NBT) dye reduction assay, as described by us in detail previously (Beere et al, 1993). The assay is based on the ability of differentiating cells to produce superoxide anion in response to TPA stimulation. For flow cytometric analysis of differentiation HL-60 cells $\left(1 \times 10^{6}\right)$ were washed twice with ice cold PBS containing $1 \%(\mathrm{w} / \mathrm{v})$ BSA and incubated in the dark for $1 \mathrm{~h}$ in $100 \mu$ PBS containing $1 \%$ (w/ v) BSA and $5 \mathrm{ml}$ monoclonal mouse anti-human CD14 antibody (clone UCHM-1), phycoerythrin conjugated (DAKO). After incubation cells were washed twice in ice cold PBS containing 1\% (w/v) BSA and immediately analyzed by flow cytometry. The simultaneously prepared controls were as follows: Cells only, cells+irrelevant FITC conjugated control Ab (DAKO).

\section{Assessment of cell viability}

Cell viability was assessed by TB uptake and $A O$ staining as described previously (Beere et al, 1995). Necrosis was defined by the inability to exclude TB. Cells which stained brightly with acridine orange $(5 \mu \mathrm{g} / \mathrm{ml})$ and exhibited condensed and/or fragmented nuclei whilst maintaining membrane integrity were scored as apoptotic. The apoptotic cells were readily distinguished from viable cells since the latter have diffuse nuclear staining patterns. Necrotic and apoptotic cells were expressed as a percentage of total cell number. A minimum of 200 cells were counted per sample.

\section{Detection of DNA fragmentation}

FIGE was performed exactly according to our previously published method (Oberhammer et al, 1993).

\section{HPLC}

High Performance Liquid Chromatography (HPLC) was performed with a Gilson HPLC pump connected to a Perkin-Elmer injector and a Milton Roy UV-detector. GTP and ATP levels were detected at $254 \mathrm{~nm}$ with a PART-SAX S/N HPLC ion exchange column and analyzed with Gilson HPLC software. For the determination of GTP levels. Cells $\left(8 \times 10^{6}\right)$ were washed twice in PBS and resuspended in $500 \mu \mathrm{l}$ TCA (10\%). After $1 \mathrm{~h}$ incubation on ice cells the suspension was 
centrifuged at 12000 r.p.m. and the supernatant resuspended in a TOC $(21 \%) / F R E O N$ solution. After separation, the top layer was analyzed for GTP concentration.

\section{Centrifugal elutriation}

Elutriation was performed at $4^{\circ} \mathrm{C}$ with a JE-5.0 Elutriation System in a Beckman $\mathrm{J} 6$ centrifuge at 1500 r.p.m. Fractions collected between flow rates of 30,32 and $34 \mathrm{ml} / \mathrm{min}$ contained HL-60 cells in G1-phase and were pooled. Cells which had not been subjected to fractionation were elutriated for $5 \mathrm{~min}$ and collected at a flow rate of $170 \mathrm{ml} / \mathrm{min}$ as a control for the elutriation process.

\section{Flow cytometry}

A Becton-Dickinson FACS Vantage was used for all procedures and data was analyzed with PC-Lysis software (BD, San Jose, CA, USA).

\section{Cell cycle analysis}

HL-60 cells $\left(5 \times 10^{5}\right)$ were fixed for at least $1 \mathrm{~h}$ in $70 \%$ ice cold ethanol and rehydrated at $4^{\circ} \mathrm{C}$ in PBS containing $2.5 \mu \mathrm{g} / \mathrm{ml}$ propidium iodide (PI) (Molecular Probes, Eugene, OR, USA) $12 \mathrm{~h}$ prior to analysis. The suspension was analyzed and red fluorescence above $630 \mathrm{~nm}$ was measured on a linear scale. In all experiments cell debris were excluded by gating procedures, as published previously (Dive et al, 1992).

For BrdU analysis, cells $\left(2 \times 10^{6}\right)$ were incubated for $30 \mathrm{~min}$ at $37^{\circ} \mathrm{C}$ with $\mathrm{BrdU}(10 \mu \mathrm{M})$ and washed twice in PBS containing $1 \% \mathrm{BSA}$. Pellets were resuspended in $100 \mu \mathrm{l}$ PBS and fixed in $70 \%$ ethanol $\left(-20^{\circ} \mathrm{C}\right)$ for $30 \mathrm{~min}$. Cells were centrifuged at 1600 r.p.m. for $10 \mathrm{~min}$ and added to $1 \mathrm{ml}$ of $2 \mathrm{~N} \mathrm{HCl}$ containing $0.5 \%$ Triton X-100. Cells were then centrifuged at 1600 r.p.m. and added to $1 \mathrm{ml}$ of $0.1 \mathrm{M}$ sodium tetraborate $\left(\mathrm{pH} \mathrm{8.5)} .10^{6}\right.$ cells were aliquoted, centrifuged at 1600 r.p.m. for $5 \mathrm{~min}$ and resuspended in $50 \mu \mathrm{l}$ PBS containing 1\% BSA and $0.5 \%$ Tween 20. The suspension was incubated for $30 \mathrm{~min}$ with $20 \mu \mathrm{l}$ anti BrdU antibody directly conjugated to FITC (BectonDickinson, San Jose, CA, USA). Samples were centrifuged for $5 \mathrm{~min}$ and resuspended in $1 \mathrm{ml}$ PBS. PI $(5 \mu \mathrm{g} / \mathrm{ml})$ was added prior to analysis. Data were analyzed as two dimensional frequency contour plots of forward light scatter versus log red fluorescence after exclusion of cell debris and doublets. Cells with a DNA content lower than those of G1 were assumed to be apoptotic.

\section{Fluorescence activated cell sorting}

For FACS cells were incubated for 5 min with $10 \mu \mathrm{g} / \mathrm{ml} \mathrm{Hoechst} 33342$ and data immediately analyzed as two dimensional contour plots of blue fluorescence versus forward light scatter. Apoptotic and viable cell populations were sorted into ice cold PBS, whereas necrotic cells were discarded by gating (Dive et al, 1992).

\section{TdT assay}

This was performed exactly as described by Gorczyca et al (1993). Briefly, after drug treatment, HL-60 cells were collected by centrifugation and fixed in $1 \%$ formaldehyde in PBS for 15 min on ice. After centrifugation the pellet was resuspended in $200 \mu$ of PBS, and $1 \mathrm{ml}$ of $70 \%$ ice cold ethanol was added immediately. Samples were stored (for $1-4$ days) at $4{ }^{\circ} \mathrm{C}$ until analysis. After rehydration in PBS for $15 \mathrm{~min}$, the cells were resuspended in $50 \mu \mathrm{l}$ of cacodylate,

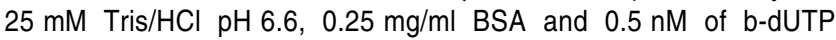

(Boehringer Mannheim) and were incubated at $37^{\circ} \mathrm{C}$ for $30 \mathrm{~min}$. Cells were then washed in PBS, resuspended in $100 \mathrm{ml}$ of staining buffer $(2.5 \mathrm{ng} / \mathrm{ml}$ fluoresceinated avidin, $4 \times$ saline sodium citrate buffer $(1 x=0.15 \mathrm{M} \mathrm{NaCl}, 0.015 \mathrm{~m}$ sodium citrate, $\mathrm{pH} 7.0), 0.1 \%$ Triton $\mathrm{X}$ $100,5 \%, w / v$, nonfat dry milk), and incubated for $30 \mathrm{~min}$ at room temperature in the dark. The cells were then rinsed in PBS, containing Triton X-100 and were resuspended in $0.5 \mathrm{ml}$ of PBS containing propidium iodide ( $3.2 \mathrm{mM})$, for $5 \mathrm{~min}$ before analysis. Briefly, TdT incorporated b-dUTP was visualized by fluoresceinated avidin (green fluorescence), and cell cycle phases determined by the binding of propodium to DNA (red fluorescence).

\section{Immunoblot analysis}

Cells $\left(4 \times 10^{6}\right)$ were washed in PBS and sonicated in sample buffer (50 mM Tris/HCl pH 7.4, $0.25 \mathrm{M} \mathrm{NaCl}, 5 \mathrm{mM}$ EDTA, $50 \mu \mathrm{g} / \mathrm{ml} \mathrm{PMSF}$, $1 \mu \mathrm{g} / \mathrm{ml}$ aprotinin) using a MSE soniprep 150. Protein concentration was determined using a BCA protein assay (PIERCE Warriner, Ltd, UK) and samples diluted to equal concentrations with sample buffer. Cellular protein was separated on a $10 \%$ SDS-polyacrylamide gel under reducing conditions. Proteins were transferred to Immobilon- $P$ (Millipore) and blocked overnight in PBS containing 5\% Marvel and $0.1 \%$ Tween 20. Membranes were probed with anti-Rb Ab G3-245 (Pharmingen) and anti-c-Myc Ab-1 (Calbiochem). To ensure equal loading and transfer, membranes were probed with anti-Hsc70 Ab 1 B5 (Bioquote Ltd.). Membranes were then incubated with horse radish peroxidase conjugated secondary antibodies and bands were visualised by using ECL Western blotting detection reagents (Amersham International).

\section{Acknowledgements}

This research was supported by a studentship from the Cancer Research Campaign to AG.

\section{References}

Ahmed N and Weideman MJ (1995) Biochemical effect of three different inhibitors of purine/pyrimidine metabolism on differentiation in HL-60 cells. Leuk. Res. 19: $263-273$

Allison AC, Kowalski WJ, Muller CD and Eugui EM (1993) Mechanism of action of mycophenolic acid. Am. N.Y. Acad. Sci. 696: 63-87

An B and Dou QP (1996) Cleavage of retinoblastoma protein during apoptosis: an interleukin $1 \beta$-converting enzyme-like protease as canidate. Cancer Res. 56 : $438-442$

Beere HM, Chresta CM, Alejo-Herberg A, Skladanowski A, Dive C, Larsen K and Hickman JA (1995) Investigation of the mechanism of higher order chromatin fragmentation observed in drug-induced apoptosis. Mol. Pharmacol. 47: 986996

Beere HM and Hickman JA (1993) Differentiation: a suitable strategy for cancer chemotherapy? Anti-Cancer Drug Design 8: 299-322

Beere HM, Hickman JA, Morimoto RI, Parmar R, Newbould R and Waters CM (1993) Changes in hsc70 and c-myc in HL-60 cells engaging differentiation or apoptosis. Mol. Cell. Diff. 1: $323-343$

Birnie GD (1988) The HL-60 cell line: a model system for studying human myeloid cell differentiation. Br. J. Cancer 9: 41-45

Bodner AJ, Ting RC and Gallo RC (1981) Induction of differentiation of human promyelocytic leukemia cells (HL-60) by nucleosides and methotrexate. J. Clin. Invest. 67: 1025-1030

Brown DG, Sun XM and Cohen GM (1993) Dexamethasone-induced apoptosis involves cleavage of DNA to large fragments prior to internucleosomal fragmentation. J. Biol. Chem. 268: 3037-3039 
Bunce CM, Wallington LA, Harrison P, Williams GR and Brown G (1995) Treatment of $\mathrm{HL}-60$ cells with various combinations of retinoids and $1 \mathrm{a}, 25$ dihydroxyvitamin D3 results in differentiation towards neutrophils or monocytes or a failure to differentiate and apoptosis. Leukemia 9: 410-418

Catapano CV, Dayton JS, Mitchell BS and Fernandes DJ (1995) GTP depletion induced by IMP dehydrogenase inhibitors blocks RNA-primed DNA synthesis. Mol. Pharm. 47: $948-955$

Cohen MB, Maybaum J and Sadee W (1981) Guanine nucleotide depletion and toxicity in mouse T lymphoma (S-49) cells J. Biol. Chem. 256: 8713-8717

Dive C and Hickman JA (1991) Drug-target interactions: only the first step in the commitment to a programmed cell death. Br. J. Cancer 64: 192-196

Dive C, Gregory CD, Phipps DJ, Evans DL, Milner AE and Wyllie AH (1992) Analysis and discrimination of necrosis and apoptosis (PCD) by multiparameter flow cytometry. Biochem. Biophys. Acta 1133: 275-285

Eugui EM, Almquist S, Muller CD and Allison AC (1990) Lymphocyte-selective cytostatic and immunosuppressive effects of mycophenolic acid in vitro: role of deoxyguanosine nucleotide depletion. Scand. J. Immunol. 33: 161-173

Franklin TJ and Cook JM (1969) The inhibition of nucleic acid synthesis by mycophenolic acid. Biochem. J. 113: 515-524

Gallagher R, Collins S and Trujillo J (1979) Characterization of the continuous, differentiating myeloid cell line $(\mathrm{HL}-60)$ from a patient with acute promyelocytic leukemia. Blood 54: 713-733

Gorczyca W, Gong J and Darzynkiewicz Z (1993) Detection of DNA strand breaks in individual apoptotic cells by the in situ terminal deoxynucleotidyl transferase and nick translation assays. Cancer Res. 53: 1945-1951

Kiguchi K, Collart FR, Hennin-Chubb C and Huberman E (1990) Cell differentiation and altered IMP dehydrogenase expression induced in human t-lymphoblastic leukemia cells by mycophenolic acid and tiazofurin. Exp. Cell. Res. 187: 47-53

Langdon SP and Hickman JA (1987) Correlation between the molecular weight and potency of polar compounds which induce the differentiation of $\mathrm{HL}-60$ human promyelocytic leukemia cells. Cancer Res. 47: 140-147

Linke SP, Clarkin KC, Di Leonardo A, Tsou A and Wahl GM (1996) A reversible, p53dependent G0/G1 cell cycle arrest induced by ribonucleotide depletion in the absence of detectable DNA damage. Genes and Dev. 10: 934-947
Lowe JK, Brox L and Henderson JF (1977) Consequences of inhibition of guanine nucleotide synthesis by mycophenolic acid and virazole. Cancer Res. 37: $736-$ 743

Lucas DL, Webster HK and Wright DG (1983) Purine metabolism in myeloid precursor cells during maturation: studies with the HL-60 cell line. J. Clin. Invest. 72: $1889-1900$

Martin SJ, Bradley JG and Cotter TG (1990) HL-60 cells induced to differentiate towards neutrophils subsequently die via apoptosis. Clin. Exp. Immunol. 79: $448-453$

Moorman J, Gilmer L, Hahn C and Bobak D (1996) Inactivation of the small G-protein rho disrupts cellular adhesion and spreading and activates apoptosis. J. Med. Invest. 44: $240 \mathrm{~A}$

OberhammerF, Wilson JW, Dive C, Morris ID and Hickman JA (1993) Apoptotic death in epithelial cells: cleavage of DNA to 300 and/or 50 kilobase fragments prior to or in the absence of internucleosomal fragmentation. EMBO Journal 12: 3679 3684

Pratt WB, Ruddon RW, Ensminger WD and Maybaum J (1994) The anticancerdrugs. Oxford University Press, Oxford

SintchakM, Fleming MA, Futer O, Raybuck SA, Chambers SP, Caron PR, Murcko MA and Wilson KP (1996) Structure and mechanism of inosine monophosphate dehydrogenase in complex with the immunosuppressant mycophenolic acid Cell 85: $921-930$

Sokoloski JA, Blair OC and Sartorelli AC (1986) Alterations in glycoprotein synthesis and guanosine triphosphate levels associated with the differentiation of $\mathrm{HL}-60$ leukemia cells produced by inhibitors of ionosine 5 '-phosphate dehydrogenase. Cancer Res. 46: 2314-2319

Sokoloski JA and Sartorelli AC (1985) Effects of the inhibitors of IMP dehydrogenase, tiazofurin and mycophenolic acid on glycoprotein synthesis. Mol. Pharm. 28: 567-573

Yan GM, Lin SZ, Irwin RP and Paul SM (1995) Activation of G-proteins birectionally affects apoptosis of cultured cerebellar granule neurons. J. Neurochem. 65: $2425-2431$ 